\title{
Species of lichenized Ascomycota new to Polish Western Carpathians and rare in whole Carpathians
}

\author{
Paweł Czarnota* \& Magdalena Tanona \\ University of Rzeszów, Department of Ecology and Environmental Protection, Zelwerowicza 4 Street, \\ 35-601 Rzeszów, Poland. *E-mail: pczarnota1@gmail.com
}

\begin{abstract}
Five species of lichen-forming fungi not reported yet or rare in the Carpathians have been found during lichenological researches by authors in the Tatra Mts and the Gorce Mts. Of these, Tetramelas chloroleucus has not been recorded in Poland since $19^{\text {th }}$ century and, similarly to Gyalecta russula, has been found for the first time in the Polish part of the Carpathians. Absconditella celata has been discovered in the Polish Western Carpathians. Fellhanera gyrophorica has never been listed before in the Western Carpathians and Epigloea bactrospora in whole Carpathians. Notes on the taxonomy, habitat and worldwide distribution of these species (including maps of their ranges in Europe) are accompanied by photo plates illustrating their morphology and anatomy.
\end{abstract}

Keywords: biodiversity, Carpathians, lichens, rare species, new records, lichen checklist

\section{INTRODUCTION}

The lichen diversity in the Carpathians has been studied for over 150 years (for detailed references see, i.a., Bielczyk et al., 2004; Ciurchea, 2007; Vondrák et al., 2010). Some regions have local, detailed studies, while others are still poorly explored. In recent years, the best preserved old-growth forests and oakwood pastures in the eastern part of this mountain range have become the spectacular object of lichenological interest, resulting in a significant enrichment of the Carpathian and regional species lists (i.a., Vondrák et al., 2009, 2015; Ardelean et al., 2013; Dymytrova et al., 2013; Czarnota et al., 2018; Malíček et al., 2014, 2018a), including lichenized fungi new to science (Malíček et al., $2018 b, 2020)$. Also recent taxonomic revisions supported by molecular data reveal a greater species richness of lichens in the Carpathians than previously thought (i.a., Frolov et al., 2016; Guzow-Krzemińska et al., 2016; Malicek et al., 2017). In the Polish Carpathians, the most intensive field research, covering almost all ranges of these mountains, took place in the last century (see Bielczyk, 2003; Kiszka \& Kościelniak, 2003). Currently, in the era of new challenges in science, reports of new discoveries or noteworthy lichen species appear less and less often (Flakus, 2014). Therefore, the records of the species previously unknown in this part of the Carpathians seem to be particularly valuable. The presentation of several of these species, with their distinctive features, as well as their current distribution in Europe is the purpose of this work. No less important motivation is the compilation of the list of all known lichenforming species in the Carpathians prepared as Polish part of an international project led by Dr. A. Bérešová (SAV Bratislava).

\section{MATERIAL AND METHODS}

Lichens were collected by the authors from the beginning of this century during several field explorations in Polish Western Carpathians focused on: 1) lichen-bryophyte communities inhabiting sandstone outcrops (PC), 2) diversity and ecology of wood-inhabited fungal species (PC \& MT), 3) lichen diversity within the zones established to protect Western Carpathian Lobaria pulmonaria (L.) Hoffm. population (PC), and 4) forest ecology studies on permanent monitoring plots (PC). Most noteworthy species including new to Poland, the Carpathians or the Polish part of this mountain range have already been published (i.a., Czarnota, 2011, 2015, 2016; Czarnota \& Hernik, 2013; Czarnota et al., 2018; Kukwa et al., 2017); five more are mentioned here.

Specimens were identified under stereomicroscope Zeiss Stemi DV4 and light-microscope Zeiss Axiostar Plus using routine lichenological methods, including morphological and anatomical characters, spot test reactions with $\mathrm{KOH}, \mathrm{Na}-$ 
$\mathrm{ClO}, \mathrm{C}_{6} \mathrm{H}_{4}\left(\mathrm{NH}_{2}\right)_{2}$ [ethanolic p-phenylenediamine solution], TLC analyses (Orange et al., 2001) and the reaction with UV light. Collections have been deposited in the herbarium of Gorce National Park (GPN). The nomenclature follows Fałtynowicz and Kossowska (2018), with the support of Baloch et al. (2013) for Gyalecta russula, and Nordin (2004) for Tetramelas chloroleucus. Distribution maps (Figs 1D, 2D, 3C, 4E, 5D) are based on literature and on-line data and are updated with the authors' data listed in this article.

\section{THE SPECIES}

Absconditella celata Döbbeler \& Poelt

Specimens examined: Poland, Carpathians: Tatra Mts, Tatra National Park, forest section 261h, Tomanowa Dolina valley, Zadni Smreczyński Grzbiet area, alt. ca. $1420 \mathrm{~m}, 49^{\circ} 13^{\prime} 13.3$ "N, 1953'04.3"E, Atpol Gd59, on decaying wood of decorticated Picea abies trunk, leg. P. Czarnota 7016 (GPN); Western Beskidy Mts, Gorce Mts, Gorce National Park, forest section no. 97, alt. $1146 \mathrm{~m}, 49^{\circ} 34^{\prime} 07.07$ 'N, 20¹1'16.91"E, Atpol Ge21, on decaying wood of spruce log, 10.07.2018, leg. M. Tanona, F. Karpowicz \& P. Czarnota 8409 (GPN); ibid., valley of Forendówki stream, forest section no. $168 \mathrm{~b}$, alt. $1150 \mathrm{~m}, 4^{\circ} 32$ '21"N, 2009'36”E, Atpol. Ge21, on lignum of decaying spruce log in an upper mountain spruce forest Plagiothecio-Piceetum, 2019, leg. M. Tanona \& P. Czarnota 8453 \& 8454 (GPN).

Although $A$. celata is a very inconspicuous lichen-forming fungus with a thallus resembling free-living wood-inhabited algae, its minute perithecia-like apothecia of orange colour and 3-septate fusiform ascospores (Fig. 1A-C) are very distinct diagnostic features that distinguish it from several other microlichens. The most similar species in appearance of ascocarps are representatives of Psoroglaena genus, i.e. $P$. abscondita (Coppins \& Vězda) Hafellner \& Türk and $P$. dictyospora (Orange) H. Harada. These species form pale orange perithecia, however, without an open ostiolae and hamathecium composed of only periphyses (there are no interascal filaments) in contrast to hamathecium of simple, slightly widening paraphyses in $A$. celata. Ascospores of $P$. abscondita can also be 3-septate (1-3-septate), but more elongate than fusiform, and its thallus is minutely leprose. $P$. dictyospora forms even more leprose thallus and muriform ascospores. The three species can inhabit similar substrata, growing on a dead wood, decaying lichens and bryophytes in natural as well as post-mining habitats (Czarnota, unpubl. data). Porina leptalea (Durieu \& Mont.) A.L. Sm. can also resemble A. celata due to its orange, hemispherical ascocarps, thin, smooth, olive-green, crustaceous thallus, and 3-septate, fusiform ascospores. The fruit bodies of P. leptalea are in fact perithecia surrounded by Porina-yellow pigmented involucreum with paraphysioid hamathecium; its photobiont belongs to Trentepohlia, while in A. celata the photobiont is chlorococcoid. Both species prefer also different habitats since $P$. leptalea is a corticolous lichen.

Absconditella celata was not reported to date from Polish Western Carpathians being known from single localities in Slovak Carpathians (Palice, 1999) and Polish Eastern Carpathians (Bielczyk \& Kiszka, 2002). Its distribution includes, moreover, mainly temperate to cold regions of Scandinavia (Holien et al., 2016; Döbbeler \& Poelt, 1977; Palice, 1999), Estonian Saaremaa Island on Baltic Sea (Aptroot et al., 2005), Tver Region in European Russia (Notov et al., 2011), the Czech Republic (Palice, 1999; Malíček \& Palice, 2013; Malíček et al., 2019; Vondrák, unpubl. data available in http:// botanika.bf.jcu.cz, accessed on 3.10.2019) and British Isles (Coppins, 2009; https://species. nbnatlas.org/species/NHMSYS0001472736, accessed on 3.10.2019) (Fig. 1D). Single reports from British Columbia in North America (Spribille et al., 2009), and Tasmania (Kantvilas \& Jarman, 2012) and South Siberia in Russia are also known (Urbanavichene \& Palice, 2016).

In the two Polish localities this microlichen was found to be growing on dead wood in subalpine belt covered with Norway spruce stands more or less destroyed by bark-beetle outbreaks. It was accompanied there by Micarea nowakii Czarnota \& Coppins s.1. (the sister taxon to Micarea herbarum M. Brand, Coppins, Sérus. \& van den Boom; see Guzow-Krzemińska et al., 2019), $M$. misella (Nyl.) Hedl., Placynthiella dasaea (Stirt.) Tønsberg and Thelocarpon epibolum Nyl.

\section{EPIGLOEA BACTROSPORA Zukal}

Specimen examined: Poland, Carpathians, Western Beskidy Mts, Gorce Mts, Gorce National Park, forest section no. 128, on decaying wood of spruce log within Carpathian beech forest, 49 $33^{\prime} 26.90^{\prime \prime} \mathrm{N}$, 20¹3'55.83"E, alt. 1050 m, Atpol Ge21, 3.08.2018, leg. M. Tanona \& P. Czarnota 8442 (GPN). 


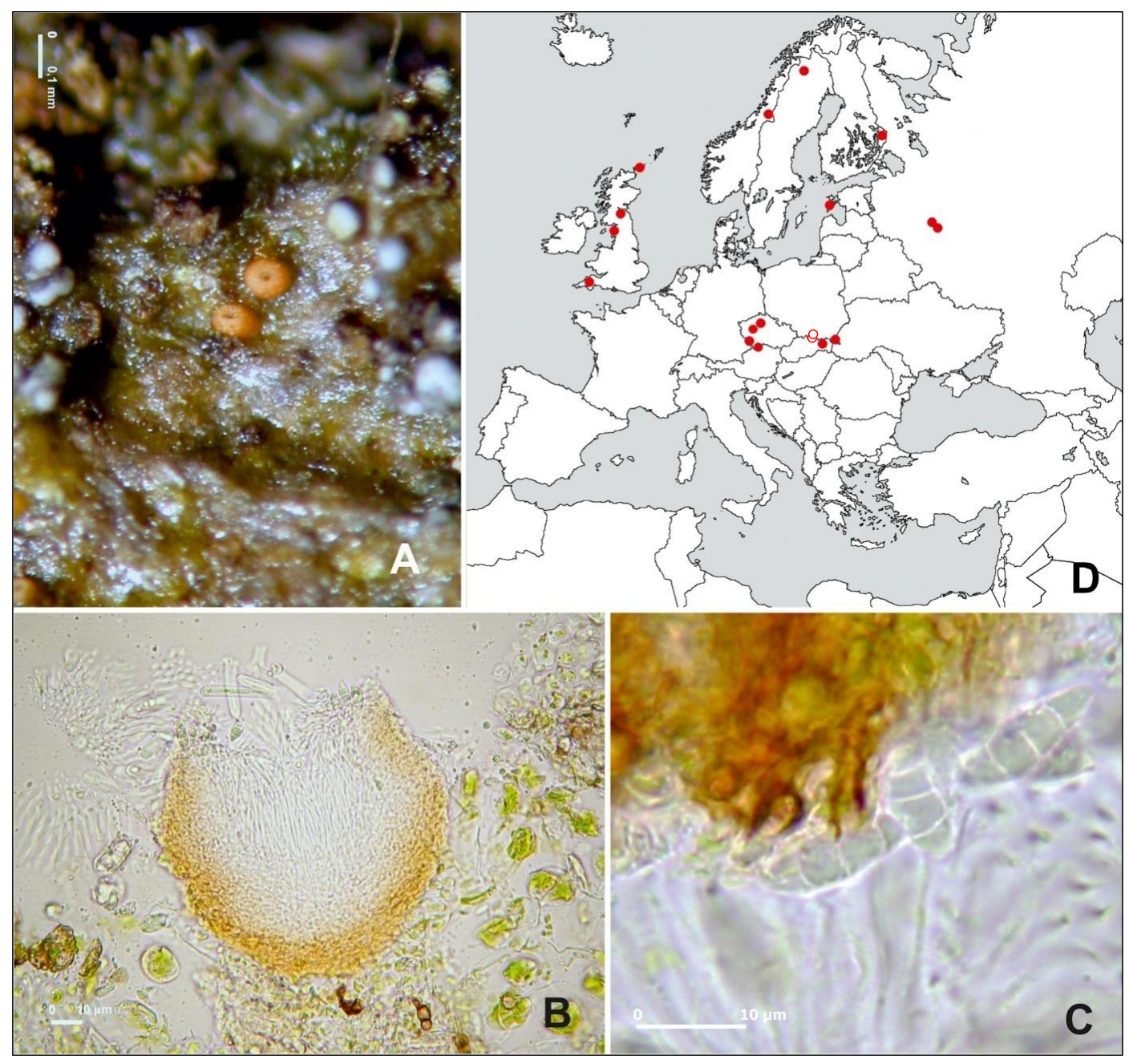

Fig. 1. Absconditella celata Döbbeler \& Poelt: A - habit, B - ascomatal cross section, C - ascospores (A-C: leg. M. Tanona, F. Karpowicz \& P. Czarnota 8409; GPN), D - distribution in Europe; circles - localities known to date, rings - new localities in the Carpathians.

This minute species represents algicolous fungi associated with Coccomyxa. The relationship of both lichen components is probably not only symbiotic as mycobiont is sometimes parasitic depending on environmental conditions and the stage of its development (Jagg \& Thomas, 1934). Epigloea bactrospora mostly resembles E. pleiospora Döbbeler in its narrowly elongate 1-septate ascospores and multispored asci, but the ascospores of $E$. bactrospora are slightly narrower $(6.0-11.0 \times 1.5-2 \mu \mathrm{m}$ while in E. pleiospora reach $5.5-11.5 \times 2-3 \mu \mathrm{m})$ and asci produce more than 32 spores contrary to the less then 32-spored asci in E. pleiospora (see Fig. 2A-C). For excellent descriptions of both species see Döbbeler (1984) and Ceynowa-Giełdon (2002).

Epigloea bactrospora is rarely reported from only dispersed localities throughout Europe (Fig. 2D): Norway (GBIF Norway; https://artskart. artsdatabanken.no, accessed on 3.10.2019), Denmark and Schleswig-Holstein (Jacobsen, 1990), the Netherlands (Aptroot et al., 1999), northern Poland (Ceynowa-Giełdon, 2002, 2005), montainous regions of Austria, Germany, Italy (Grummann, 1968; Döbbeler, 1984; Nimis 



Fig. 2. Epigloea bactrospora Zukal: A - habit, B - hamathecium and asci filled in ascospores, $\mathrm{C}$ - ascomatal cross section (A-C: leg. M. Tanona \& P. Czarnota 8442; GPN), D - distribution in Europe; circles - localities known to date, ring - new locality in the Carpathians.

et al., 2018), and Switzerland (Jaag \& Thomas, 1934); recently it has been also found in the Czech Republic (Vondrák, unpubl. data available in http://botanika.bf.jcu.cz, accessed on 12.12.2019). Here E. bactrospora is recorded for the first time in the Carpathians.

Fellhanera GYrophorica Sérus., Coppins, Diederich \& Scheid.

Specimens examined: Poland, Carpathians, Western Beskidy Mts, Gorce Range, Gorce National Park, valley of Kamienica river, 49³3'34.09”N, 20¹2'17.15”E, alt.
930 m, Atpol Ge21, on bark of Fagus sylvatica in the Carpathian beech forest, 11.08.2015, leg. P. Czarnota 8023, L. Widak, K. Wąsik (GPN); ibid., N slope of Kudłoń Mt below Stawieniec glade, forest section no. $101 \mathrm{a}$, close to the Kamienica river, 49 $33^{\prime} 35.72^{\prime \prime N}$, $20^{\circ} 11^{\prime 4} 8.69 " \mathrm{E}$, alt. $890 \mathrm{~m}$, Atpol Ge21, on bark of Fagus sylvatica in old-growth Carpathian beech forest, 23.11.2018, leg. P. Czarnota 8434 (GPN).

A description of the species based on only pycnidial stage had been made by Serusiaux et al. (2001) with an excellent comparison to other crustose corticolous species producing similar 
\pm stipitate, barrel-like and widely gapping pycnidia, namely Micarea pycnidiophora Coppins \& P. James, Micarea doliiformis (Coppins \& P. James) Coppins \& Sérus., and Fellhanera ochracea Sparrius \& Aptroot. Systematic position of $F$. gyrophorica was proposed to be provisional that time due to pyriform conidia likely in other species of the genus. The doubt was soon clarified by Sparrius (2002) who recorded its fertile specimens. Other excellent taxonomical and ecological notes was made by Kubiak (2011) based on many collections of $F$. gyrophorica from Polish lowland. His and author's (PC) investigations of Polish herbaria materials showed that the species was formerly collected many times with apothecia (especially in the Białowieża Primeval Forest) but misidentified mostly as $\mathrm{Ba}$ cidina sulphurella (Samp.) M. Hauck \& V. Wirth (see Cieśliński \& Tobolewski, 1988 as Bacidia arnoldiana (Körb.) V. Wirth \& Vězda).

Fellhanera gyrophorica has most frequently been found in central-eastern European lowland including NE Poland, Belarus, Lithuania, Estonia and W Russia growing in well-preserved, humid, broad-leaved forests and old manor parks (Czyżewska et al., 2001; Sérusiaux et al., 2001; Motiejūnaité \& Prigodina-Lukošienè, 2002; Sparrius, 2002; Golubkov \& Kukwa, 2006; Łubek, 2009; Kubiak, 2011; Yatsyna, 2014; Stepanchikova et al., 2018; Yatsyna et al., 2018). There it is regarded as an indicator of lowland old-growth forests (Motiejūnaitè et al., 2004). In southern, mountainous part of Poland this crustaceous epiphyte has never been found to date, but it has been rarely recorded here and there in other mountainous regions of Central Europe including Switzerland, Austria, Luxembourg (Sérusiaux et al., 2001), Germany (Wirth et al., 2013), the Czech Republic (Maliček \& Palice, 2013), and in Slovak and Ukrainian Eastern Carpathians (Sérusiaux et al., 2001; Pisút et al., 2007; Malíček et al., 2018a; Fig. $3 \mathrm{C})$; recently this lichen has been also found in Caucasus (Vondrák et al., 2019). Everywhere in mountains it is mostly confined to old-growth, mainly beech forests, and therefore, also in montane environment, $F$. gyrophorica could be an indicator of most natural or primeval forest ecosystems. Here it is reported for the first time from Polish Carpathians.

Gyalecta Russula (Körb. ex Nyl.) Baloch, Lumbsch \& Wedin, $\equiv$ Belonia russula Körb. ex Nyl., = Belonia fennica Vain., = Beloniella cinerea Norman

Gagarina (2015) included also Gyalecta lyngei Baloch \& Lücking, formerly Belonia arctica Lynge [invalid name, see Baloch et al. (2013)] as a synonym for this name, but without revision of the type specimen which is stored in O.

Specimen examined: Poland, Carpathians, Gorce Mts, Gorce National Park, N slope of Kudłoń Mt, forest section no. $12 \mathrm{c}, 49^{\circ} 34^{\prime} 36.2 ” \mathrm{~N}, 20^{\circ} 10^{\prime} 16.2$ "E, alt. $1120 \mathrm{~m}$, Atpol Ge11, on calcareous sandstone wall of

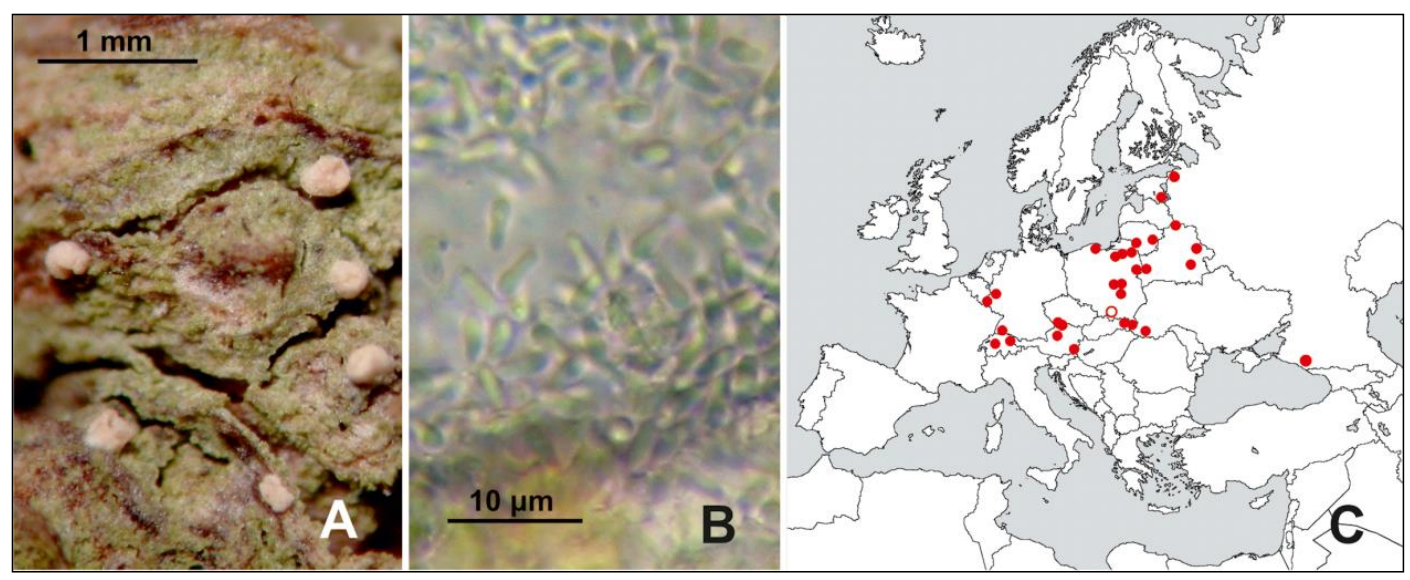

Fig. 3. Fellhanera gyrophorica Sérus., Coppins, Diederich \& Scheid: A - habit of pycnidial stage, B - pycnospores (A-B: leg. P. Czarnota 8434; GPN), C - distribution in Europe; circles - localities known to date, ring - new locality in the Carpathians. 
Kudłoński Baca outcrop, 20.06.2014, leg. P. Czarnota 8437 (GPN).

This epilithic lichen inhabiting more or less basic rocks was described few times by different lichenologists as to belong to different genera, but recent phylogenetic studies by Baloch et al. (2010) nested it again within Gyalecta.

The thallus of this lichen contains Trentepohlia algae, which is usually reflected in a reddish tinge of its thallus (see e.g. Purvis \& Orange, 2009). In the case of the Polish finding, its inconspicuous perithecia-like fruiting bodies are immersed in pale yellowish green thallus warts (Fig. 4C \& D) without any reddish tinge, its less than 20-septate worm-like ascospores reached 60-80(-85) $\mu \mathrm{m}$ in length (Fig. 4B), and some part of asci seem to be 4-spored (Fig. 4A). These characteristics could refer to Gyalecta calcicola (Walt. Watson) Baloch \& Lücking (see Purvis \& Orange, 2009; Gagarina, 2015). Taxonomic position of this species, known only from Great Britain is, however, controversial; Purvis and Orange (2009) suggested that it could be conspecific with $G$. russula. We decided to keep our finding as $G$. russula, since its thallus is distinctly su-

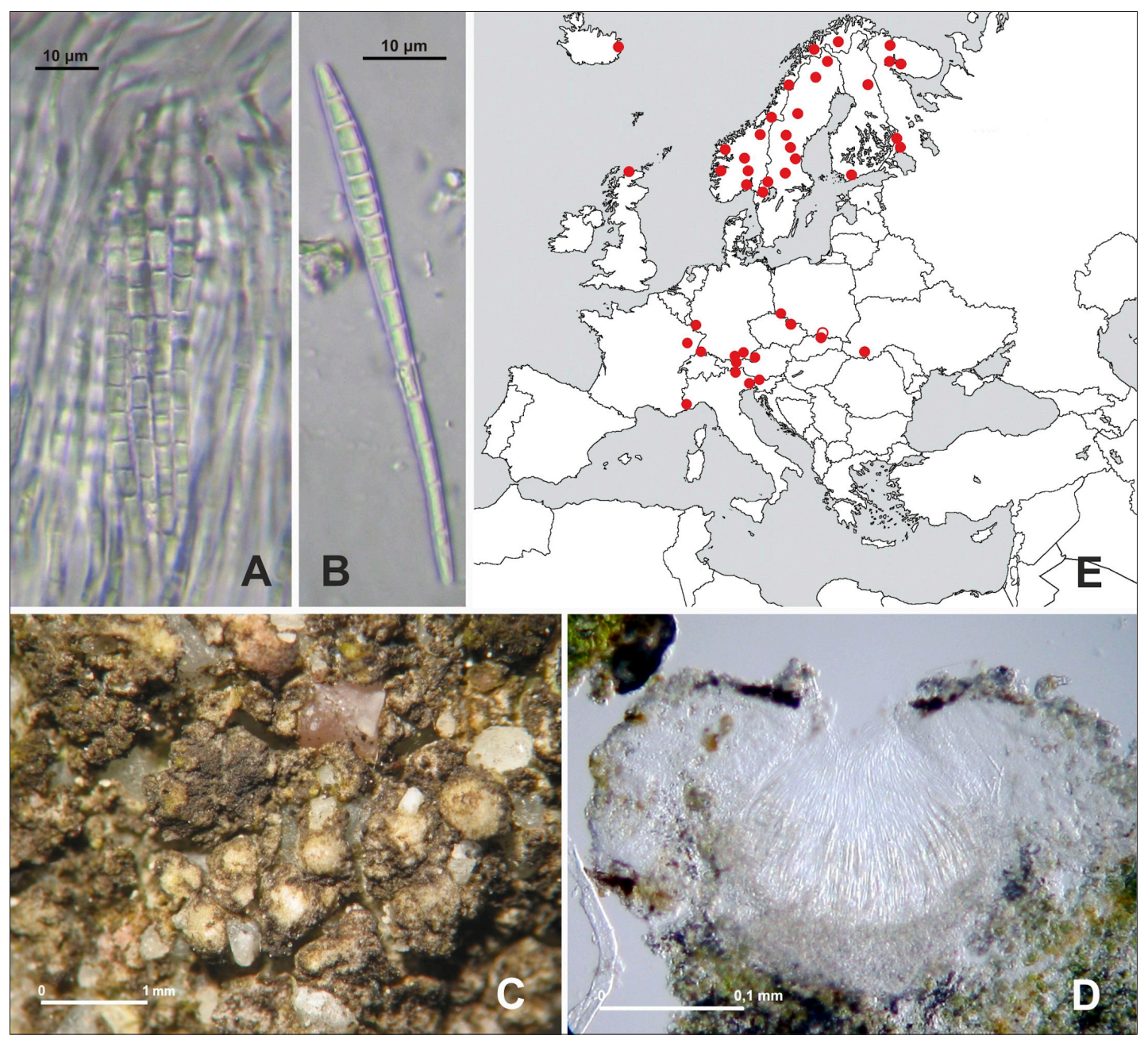

Fig. 4. Gyalecta russula (Körb. ex Nyl.) Baloch, Lumbsch \& Wedin: A - hamathecium and ascus filled in ascospores, B - ascospore, C - habit, D - ascomatal cross section (A-D: leg. P. Czarnota 8437; GPN), E - distribution in Europe; circles - localities known to date, ring - new locality in the Carpathians. 
perficial, minutely areolate and inhabits slightly calcareous substrata contrary to semi-immersed thallus of $G$. calcicola which was found to date on limestones. The pale coloured thallus warts are probably due to usually dead additional algal cells reaching up to $25 \mu \mathrm{m}$ in diam. and surrounded by gelatinous, thick walls of $3 \mu \mathrm{m}$ in width. Moreover, Nimis and Martellos (2017) noted also, that G. russula found in Italian Alps can form pale yellowish grey verrucules, what seems to refer to our Polish finding.

Gyalecta russula is regarded as an alpine-arctic, probably circumpolar species (Nimis et al., 2018) since it is known in the whole Scandinavia, especially mountainous regions of Norway and Sweden, European NW Russia, Ural, Siberia and alpine as well as subalpine belts in mountains of Central Europe (Eitner, 1910; Vězda, 1959; Urbanavichus \& Andreev, 2010; Wirth et al., 2013; Gagarina, 2015, and literature cited therein; https://artskart.artsdatabanken.no/ app, accessed on 7.08.2019; Nimis et al., 2018), also in Scotland (Purvis \& Orange, 2009), Alaska (Thomson \& Sowl, 1989; Amchitka Island), Iceland (Kristinsson, 1999) and Greenland (Alstrup et al., 2009). This species has recently been also reported from Polish part of Sudetes being rediscovered after c. 150 years in the $l_{0}$ cus classicus of Giant Mountains (Kossowska, 2011). Several Carpathian records of G. russula are known in the Slovak part of Tatra Mts (see Lisická, 2005) and in the Ukrainian part of Eastern Carpathians, namely Czornohora Mts (Black Mountain) (Vondrák et al., 2010, and literature cited therein). In Polish Carpathians this saxicolous species has never been recorded before thus here it is the only locality in this part of the Carpathians.

Tetramelas chloroleucus (Körb.) A. Nordin, $\equiv$ Buellia chloroleuca Körb.; = B. poeltii T. Schauer; $=$ Tetramelas poeltii (T. Schauer) Kalb

Specimen examined: Poland, Western Carpathians, High Tatra Mts, Tatra National Park, forest sec. no 47c, NW slope of Żabia Gran Mt near the border of Slovakia, $49^{\circ} 12^{\prime} 40^{\prime \prime N}, 20^{\circ} 05^{\prime} 24^{\prime \prime} \mathrm{E}$, alt. $1500 \mathrm{~m}$, on bark of Sorbus aucuparia at the base of trunk close to the timber-line in upper mountain spruce forest, Atpol Ge60, 09.07.2002, leg. P. Czarnota 7561 (GPN); det. M. Giralt.

This species, under the name Buellia chloroleu$c a$, was described by Körber (1865) based on the material collected in the currently Polish part of
Sudetes. Only recently Giralt et al. (2000) clearly re-defined B. chloroleuca showing characters of this species referring to Tetramelas Norman. The genus name was resurrected by Marbach (2000) for the group of Buellia s.1., which is generally characterized by the presence of xanthones (at least 6-O-methylarthothelin; see Elix, 2019), and two-layered spore wall with cracked, dark coloured perispore (Nordin, 2004). Based on the re-examined type materials, Giralt et al. (2000) synonymized also Buellia poeltii with $B$. chloroleuca. Finally, Nordin (2004) transferred this taxon to the genus Tetramelas including $T$. poeltii, the name earlier combined by Kalb (2004). The taxonomic distinction of Teramelas from the other groups of polyphyletic Buellia s.1. was supported soon by the ITS phylogeny analysis (Nordin \& Tibell 2005).

Diagnostic features of the Polish specimen (Fig. $5 \mathrm{~A}-\mathrm{C})$ correspond well with the description of T. chloroleucus by Giralt et al. (2000), including thallus $\mathrm{UV}+$ orange, $\mathrm{K}+$ and $\mathrm{C}+$ yellowish, $\mathrm{KC}+$ orange reactions (due to the presence of xanthone), brown thick-walled ascospores with perispore, bacilliform, straight, 4.5-5.5(-6) $\times$ $1 \mu \mathrm{m}$ conidia and its ecological requirements. Fałtynowicz (2003) included this species within the list of lichens in Poland using the former Körber's record and additional report by Kiszka and Kościelniak (1998). These authors excluded it, however, from their own Polish Eastern Carpathian list of lichens published in the same year (Kiszka \& Kościelniak, 2003) as probably doubtful. Considering this, T. chloroleucus is reported here from Polish Carpathians for the first time, and rediscovered in Poland after 150 years.

This boreal-montane, epiphytic or wood inhabiting species is known to be widely distributed in high mountains of Europe, especially in Pyrenees, Alps (Giralt et al., 2000; Nimis et al., 2018) and Scandinavian mountains (Nordin, 2000). It has only recently been found in Carpathians, i.e. in Ukrainian (Dymytrowa et al., 2013) and Slovak (Vondrak et al., 2015) parts of Eastern Carpathians (Fig. 5D). Additional European records of $T$. chloroleucus are known in arctic regions of Russia (Zhdanov \& Dudoreva, 2008), Norway and Island; in boreal forests in Finland (Nordin, 2000; Bjerke et al., 2011) and Leningrad Region of Russia (Himelbrant et al., 2017). It is also reported from a distant area of Asian part of Russia (Urbanavichus \& Andreev, 2010). 


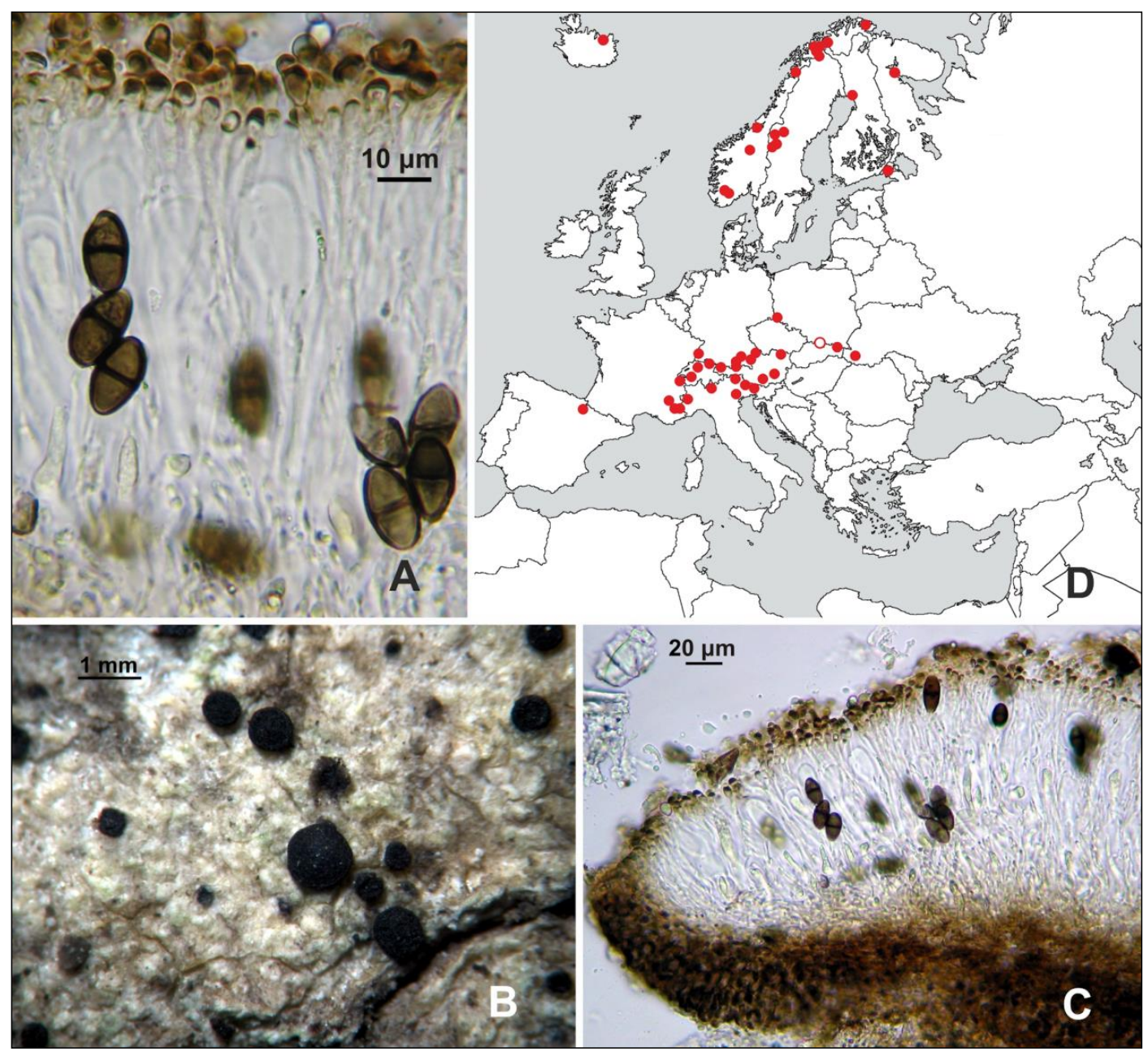

Fig. 5. Tetramelas chloroleucus (Körb.) A. Nordin: A - hamathecium with ascospores, B - habit, C - apothecial cross section (A-C: leg. P. Czarnota 7561; GPN), D - distribution in Europe; circles - localities known to date, ring - new locality in the Carpathians.

\section{ACKNOWLEDGEMENTS}

Authors thank Dr Mireia Giralt for identification of Tetramelas chloroleucus.

\section{REFERENCES}

Alstrup, V., Kocourková, J., Kukwa M., Motiejūnaitė, J., von Brackel, W. \& Suija, A. 2009. The lichens and lichenicolous fungi of South Greenland. Folia Cryptogamica Estonica 46: 1-24.

Aptroot, A., van Herk, C. M., Sparrius, L. B. \& van den Boom, P. P. G. 1999. Checklist van de Nederlandse lichenen en lichenicole fungi. Buxbaumiella 50(1): $1-64$.
Aptroot, A., Czarnota, P., Jüriado, I., Kocourkvá, J., Kukwa, M., Lõhmus, P., Palice, Z., Randlane, T., Saag, L., Sérusiaux, E., Sipman, H., Sparrius, L.B., Suija, A. \& Thüs, H. 2005. New or interesting lichens and lichenicolous fungi found during the 5th Symposium in Estonia. Folia Cryptogamica Estonica 41: 13-22.

Ardelean, I. V., Keller, C. \& Scheidegger, C. 2013. Lichen flora of Rodnei Mountains National Park (Eastern Carpathians, Romania) including new records for the Romanian mycoflora. Folia Cryptogamica Estonica 50: 101-115. https://doi. org/ $10.12697 /$ fce. 2013.50 .13

Baloch, E., Lücking, R., Lumbsch, H. T. \& Wedin, M. 2010. Major clades and phylogenetic relationships 
between lichenized and non-lichenized lineages in Ostropales (Ascomycota: Lecanoromycetes). Taxon 59: 1483-1494. https: / / doi.org/10.1002/ tax. 595013

Baloch, E., Lumbsch, H. T., Lücking, R. \& Wedin, M. 2013. New combinations and names in Gyalecta for former Belonia and Pachyphiale (Ascomycota, Ostropales) species. Lichenologist 45(6): 723-727. https://doi.org/10.1017/S0024282913000492

Bielczyk, U. 2003. The lichens and allied fungi of the Polish Western Carpathians. In: Bielczyk, U. (ed.) The lichens and allied fungi of the Polish Carpathians - an annotated checklist. Pp. 24-232. W. Szafer Institute of Botany, Polish Academy of Sciences, Kraków.

Bielczyk, U., Lackovičová, A., Farkas, E. E., Lőkös, L., Liška, J., Breuss, O. \& Kondratyuk, S. Ya. 2004. Checklist of lichens of the Western Carpathians. W. Szafer Institute of Botany, Polish Academy of Sciences, Kraków. 181 pp.

Bielczyk, U. \& Kiszka, J. 2002. Absconditella celata (Stictidaceae) - a lichen species new to Poland. Polish Botanical Journal 47(1): 70-71.

Bjerke, J. W., Mathiassen, G., Granmo, A. \& Tibell, L. 2011. Phaeocalicium compressulum new to North Norway. Graphis Scripta 23: 33-35.

Ceynowa-Giełdon, M. 2002. The genus Epigloea in Poland. Acta Mycologica 37(1/2): 3-11. https:// doi.org/10.5586/am.2002.001

Ceynowa-Giełdon, M. 2005. New localities of Epigloea bactrospora and E. pleiospora in Poland. Graphis Scripta 17: 52-55.

Cieśliński, S. \& Tobolewski, Z. 1988. Porosty (Lichenes) Puszczy Białowieskiej i jej zachodniego przedpola. Phytocoenosis 1 (N.S.), Suppl., Cartographiae Geobotanicae 1: 3-216.

Ciurchea, M. 2007. Checklist of lichens and lichenicolous fungi of Romania. http: / www.academic.ro/ lichens /Checklist.htm (accessed on 12.12.2019)

Coppins, B. J. 2009. Absconditella Vězda (1965). In: Smith, C. W., Aptroot, A., Coppins, B. J., Fletcher, A., Gilbert, O. L., James, P. W. \& Wolseley, P. A. (eds). The lichens of Great Britain and Ireland. 123-124. British Lichen Society, London.

Czarnota, P. 2011. Micarea contexta and M. lynceola (lichenized Ascomycota), new for Poland. Polish Botanical Journal 56(2): 307-313.

Czarnota, P. 2015. Lecania cuprea and Micarea pycnidiophora (lichenized Ascomycota) new to Poland. Acta Societatis Botanicorum Poloniae 84(2): 303307. https://doi.org/10.5586/asbp.2015.014

Czarnota, P. 2016. Contribution to the knowledge of some poorly known lichens in Poland IV. Bacidia fuscoviridis and Bacidina brandii. Acta Mycologica 51(1): 1074. https://doi.org/10.5586/am.1074

Czarnota, P. \& Hernik, E. 2013. Notes on two Epigloea species from Central Europe. Acta Societatis Botanicorum Poloniae 82(4): 321-324. https://doi. org/10.5586/asbp.2013.030
Czarnota, P., Mayrhofer, H. \& Bobiec, A. 2018. Noteworthy lichenized and lichenicolous fungi of open-canopy oak stands in east-central Europe. Herzogia 31: 172-189. https://doi. org/10.13158/099.031.0111

Czyżewska, K., Motiejūnaitė, J. \& Cieśliński, S. 2001. Species of lichenized and allied fungi new to Białowieża Large Forest (NE Poland). Acta Mycologica 36(1): 13-19. https://doi.org/10.5586/ am.2001.003

Döbbeler, P. \& Poelt, J. 1977. Absconditella celata spec. nov., eine Flechtenart aus Lappland. Herzogia 4: 363-366.

Döbbeler, P. 1984. Symbiosen zwinschen Gallertalgen und Gallertpilzen der Gattung Epigloea (Ascomycetes). Nova Hedwigia 79: 203-239.

Dymytrova, L., Nadyeina, O., Naumovych, A., Keller, C. \& Scheidegger, C. 2013. Primeval beech forests of Ukrainian Carpathians are sanctuaries for rare and endangered epiphytic lichens. Herzogia 26: 73-89. https://doi.org/10.13158/ heia.26.1.2013.73

Eitner, E. 1910. Dritten Nachtrag zur Schesischen Flechten flora. Schlesische Gesellschaft für vaterländische Kultur 88(2b Abth.): 20-60.

Elix, J. 2019. Notes on the genus Tetramelas (Caliciaceae, Ascomycota) in South America: Two new species from Peru, and a new combination. Opuscula Philolichenum 18: 390-395. http:// sweetgum.nybg.org/philolichenum/ (accessed on 12.12.2019)

Faltynowicz, W. 2003. The lichens, lichenicolous and allied fungi of Poland. W. Szafer Institute of Botany Polish Academy of Sciences, Kraków. 435 pp.

Fałtynowicz, W. \& Kossowska, M. 2018. The lichens of Poland. A fourth checklist. Acta Botanica Silesiaca Monographiae 8: 3-122.

Flakus, A. 2014. Lichens of the subnival belt of the Polish Tatra Mountains (in Polish, English abstract). W. Szafer Institute of Botany, Polish Academy of Sciences, Kraków. 280 pp.

Frolov, I., Vondrák, J., Fernández-Mendoza, F., Wilk, K., Khodosovtsev, A. \& Halici, M. G. 2016. Three new, seemingly-cryptic species in the lichen genus Caloplaca (Teloschistaceae) distinguished in two-phase phenotype evaluation. Annales Botanici Fennici 53(3-4): 243-262. https://doi. org/ 10.5735/085.053.0413

Gagarina, L.W. 2015. Gyalectoid lichens (families Gyalectaceae Stizenb. and Coenogoniaceae (Fr.) Stizenb. in extratropical Eurasia (in Russian). Nestor-Istoria, Sankt Petersburg. 240 pp.

Giralt, M., Barbero, M. \& Elix, J. 2000. Notes on some corticolous and lignicolous Buellia species from the Iberian Peninsula. Lichenologist 32(2): 105128. https://doi.org/10.1006/lich.1999.0251

Golubkov, V.V. \& Kukwa, M. 2006. A contribution to the lichen biota of Belarus. Acta Mycologica 41(1): 155-164. https://doi.org/10.5586/am.2006.019 
Grummann, V. J. 1968. Alte und neue Halbflechten. Ein neuer Flechten parasit. Placynthium asperellum neu für Mitteleuropa. Sydowia 22: 216-224.

Guzow-Krzemińska, B., Czarnota, P., Łubek, A. \& Kukwa, M. 2016. Micarea soralifera sp. nov., a new sorediate species in the M. prasina group. Lichenologist 48(3): 161-169. https://doi. org/10.1017/S0024282916000050

Guzow-Krzemińska, B., Sérusiaux, E., van den Boom, P. P. G., Brand, A. M., Launis, A., Łubek, A. \& Kukwa, M. 2019. Understanding the evolution of phenotypical characters in the Micarea prasina group (Pilocarpaceae) and descriptions of six new species within the group. MycoKeys 57: 1-30. https://doi.org/10.3897/mycokeys.57.33267

Himelbrant, D. E., Stepanchikova, I. S., Motiejūnaite, J., Gerasimova J. V., Kuznetsova, E. S., Dyomina, A. V. \& Tsurykau, A. G. 2017. New records of lichens and allied fungi from the Leningrad Region, Russia. VIII. Folia Cryptogamica Estonica 54: 63-70. https://doi.org/10.12697/fce.2017.54.11

Holien, H., Frisch, A., Jonsson, F., Klepsland, J. T., Millanes, A. M., Motiejunaite, J., Prieto, M., Pykäaä, J., Suija, A., Tsurykau, A., Westberg, M. \& Bendiksby, M. 2016. Interesting lichenized and lichenicolous fungi found during the Nordic Lichen Society excursion in Nord-Trøndelag, Norway 2015. Graphis Scripta 28: 40-49.

Jaag, O. \& Thomas, E. 1934. Neue Untersuchungen über die flechte Epigloea bactrospora Zukal. Berichte der Schweizerischen Botanischen Gesellschaft $=$ Bulletin de la Société botanique Suisse 43(1): 77-89.

Jacobsen, P. 1990. Epigloea bactrospora fund in Denmark and Schleswig-Holstein. Graphis Scripta 3: 19.

Kalb, K. 2004. New or otherwise interesting lichens II. Bibliotheca Lichenologica 88: 301-329.

Kantvilas, G. \& Jarman, S. J. 2012. Lichens and bryophytes in Tasmanian wet eucalypt forest: Floristics, conservation and ecology. Phytotaxa 59: 1-31. https://doi.org/10.11646/phytotaxa.59.1.1

Kiszka, J. \& Kościelniak, R. 1998. The flora of lichens in the Polish Eastern Carpathians. In: Kondratyuk, S. \& Coppins, B. J. (eds). Lobarion lichens as indicators of primeval forests of the Eastern Carpathians (Darwin International Workshop: honoured to the 100-years anniversary of a famous Ukrainian lichenologist Professor Alfred M. Oxner (1898-1973), 25-30 May 1998, Kostrino, Ukraine. Pp. 82-101. M. H. Kholodny Institute of Botany, Phytosociocentre, Kiev.

Kiszka, J. \& Kościelniak, R. 2003. The lichens and allied fungi of the Polish Eastern Carpathians. In: Bielczyk, U. (ed.). The lichens and allied fungi of the Polish Carpathians - an annotated checklist. Pp. 233-294. W. Szafer Institute of Botany, Polish Academy of Sciences, Kraków.
Kossowska, M. 2011. New, rare and noteworthy lichens in the Giant Mountains. Biologia 66(5): 755-761. https://doi.org/10.2478/s11756-0110084-4

Körber, G. W. 1865. Parerga lichenologica. Ergänzungen zum Systema Lichenum Germaniae. Verlag von Eduard Trewendt, Breslau. 501 pp. https:// doi.org/ 10.5962/bhl.title.87905

Kristinsson, H 1999. The 12th meeting of the Nordic Lichen Society in Eidar, Iceland 1997. Graphis Scripta 11(1): 13-21.

Kubiak, D. 2011. Distribution and ecology of the lichen Fellhanera gyrophorica in the Pojezierze Olsztyńskie Lakeland and its status in Poland. Acta Societatis Botanicorum Poloniae 80(4): 293300. https://doi.org/ 10.5586/asbp. 2011.035

Kukwa, M., Czarnota, P. \& Łubek, A. 2017. Three lichen species in Buellia, Catillaria, and Cheiromycina, new to Poland. Mycotaxon 132: 177-182. https:/ / doi.org/10.5248/132.177

Lisická, E. 2005. The lichens of the Tatry Mountains. Veda, Bratislava. 439 pp.

Łubek, A. 2009. New records of lichens from the Polish uplands. Acta Mycologica 44(2): 275-282. https:// doi.org/10.5586/am.2009.026

Malíček, J. \& Palice, Z. 2013. Lichens of the virgin forest reserve Žofinský prales (Czech Republic) and surrounding woodlands. Herzogia 26: 253-292. https: / / doi.org/10.13158/heia.26.2.2013.253

Malíček, J., Palice, Z. \& Vondrák, J. 2014. New lichen records and rediscoveries from the Czech Republic and Slovakia. Herzogia 27: 257-284. https://doi. org/ 10.13158/heia.27.2.2014.257

Malíček, J., Berger, F. Palice, Z. \& Vondrák, J. 2017. Corticolous sorediate Lecanora species (Lecanoraceae, Ascomycota) containing atranorin in Europe. Lichenologist 49(5): 431-455. https:// doi.org/10.1017/S002428291700038X

Malíček, J., Palice, Z., Acton, A., Berger, F., Bouda, F., Sanderson, N. \& Vondrák, J. 2018a. Uholka primeval forest in the Ukrainian Carpathians - a keynote area for diversity of forest lichens in Europe. Herzogia 31: 140-171. https://doi. org/10.13158/099.031.0110

Malíček, J., Palice, Z., Vondrák, J., Łubek, A. \& Kukwa, M. 2018b. Bacidia albogranulosa (Ramalinaceae, lichenized Ascomycota), a new sorediate lichen from European old-growth forests. MycoKeys 44: 51-62. https://doi.org/10.3897/mycokeys.44.30199

Malíček, J., Palice, Z., Vondrák, J. Kostovčỉk, M., Lenzová, V. \& Hofmeister J. 2019. Lichens in oldgrowth and managed mountain spruce forests in the Czech Republic: assessment of biodiversity, functional traits and bioindicators. Biodiversity and Conservation 28(13): 3497-3528. https:// doi.org/10.1007/s10531-019-01834-4

Malíček, J., Palice, Z., Vondrák \& Tønsberg, T. 2020. Japewia aliphatica (Lecanoraceae, lichenized 
Ascomycota), a new acidophilous sorediate-blastidiate lichen from Europe. Phytotaxa (in review).

Marbach, B. 2000. Corticole und lignicole Arten der Flechtengattung Buellia sensu lato in den Subtropen und Tropen. Bibliotheca Lichenologica 74: 1-384.

Motiejūnaitè, J. \& Prigodina-Lukošienè, I. 2002. Chaenothecopsis rubescens new to Lithuania and Fellhanera gyrophorica new to Estonia. Graphis Scripta 13: 43-44.

Motiejūnaitė, J. Czyżewska, K. \& Cieśliński, S. 2004. Lichens - indicators of old-growth forests in biocentres of Lithuania and North-East Poland. Botanica Lithuanica 10(1): 59-74.

Nimis, P. L., Hafellner, J., Roux, C., Clerc, P., Mayrhofer, H., Martellos, S. \& Bilovitz, P. O. 2018. The lichens of the Alps - an annotated checklist. MycoKeys 31: 1-634. https://doi.org/10.3897/ mycokeys.31.23568

Nimis, P. L. \& Martellos, S. 2017. ITALIC - The Information System on Italian Lichens. Version 5.0. University of Trieste, Dept. of Biology. http:// dryades.units.it/italic (accessed on 11.12.2019)

Nordin, A. 2000. Buellia chloroleuca in the Nordic Countries. Graphis Scripta 11: 35-39.

Nordin, A. 2004. New species in Tetramelas. Lichenologist 36(6): 355-359. https://doi.org/10.1017/ S0024282904014562

Nordin, A. \& Tibell, L. 2005. Additional species in Tetramelas. Lichenologist 37(6): 491-498. https:/ / doi.org/10.1017/S0024282905015434

Notov, A. A., Himelbrant, D. E. \& Urbanavichus, G. P. 2011. The list of lichens and allied fungi of Tver Region (in Russian, English abstract). Tver State University, Tver. 124 pp.

Orange, A., James, P. W. White, F. J. 2001. Microchemical methods for the identification of lichens. British Lichen Society, London. $101 \mathrm{pp}$.

Palice, Z. 1999. New and noteworthy records of lichens in the Czech Republic. Preslia 71: 289-336.

Pisút, I., Lackovičová, A., Guttová, A. \& Palice, Z. 2007. New lichen records from Bukovské Vrchy Mts (NE Slovakia). Acta Mycologica 42(2): 267-280. https://doi.org/10.5586/am.2007.030

Purvis, O. W. \& Orange, A. 2009. Belonia Körb. ex Nyl. (1857). In.: Smith, C. W., Aptroot, A., Coppins, B. J., Fletcher, A., Gilbert, O. L., James, P. W. \& Wolseley, P. A. (eds). The lichens of Great Britain and Ireland. Pp. 211-212. British Lichen Society, London.

Sérusiaux, E., Coppins, B. J., Diederich, P. \& Scheidegger, C. 2001. Fellhanera gyrophorica, a new European species with conspicuous pycnidia. Lichenologist 33(4): 285-289. https:// doi.org/10.1006/lich.2001.0328

Sparrius, L. B. 2002. Discovery of apothecia confirms generic position of Fellhanera gyrophorica. Lichenologist 34(1): 86. https://doi.org/10.1006/ lich.2002.0370
Spribille, T., Björk, C. R., Ekman, S., Elix, J. A., Goward, T., Printzen, C., Tønsberg, T. \& Wheeler, T. 2009. Contributions to an epiphytic lichen flora of northwest North America: I. Eight new species from British Columbia inland rain forests. Bryologist 112(1): 109-137. https://doi. org/10.1639/0007-2745-112.1.109

Stepanchikova, I. S., Himelbrant, D. E., Motiejūnaitè, J., Ahti, T., Suija, A., Kuznetsova, E. S. \& Dyomina, A.V. 2018. New records of lichens and allied fungi from the Leningrad Region, Russia. IX. Folia Cryptogamica Estonica 55: 117-124. https://doi. org/ $10.12697 /$ fce.2018.55.12

Thomson, J. W. \& Sowl, L. W. 1989. Additional records of lichens from Amchitka Island, Alaska. Evansia 6(1): $7-11$.

Urbanavichene, I. N. \& Palice, Z. 2016. Rarely recorded lichens and lichen-allied fungi from the territory of the Baikal Reserve - additions for lichen flora of Russia. Turczaninowia 19(1): 42-46. https:// doi.org/10.14258/turczaninowia.19.1.5

Urbanavichus, G. P. \& Andreev, M. P. 2010. A checklist of the lichen flora of Russia. Nauka, Sankt Petersburg. 194 pp.

Vězda, A. 1959. K taxonomii rozsireni a ekologii lisejniku Belonia russula Krb. v Estredni Evrope [On the distribution and ecology of the lichen Belonia russula in Central Europe]. Prirodovedny Casopsi Slezsky, Opava 20: 241-253 (in Czech).

Vondrák, J., Šoun, J., Lökös, L. \& Khodosovtsev, A. 2009. Noteworthy lichen-forming and lichenicolous fungi from the Bükk Mts, Hungary. Acta Botanica Hungarica 51(1-2): 217-230. https:// doi.org/10.1556/ABot.51.2009.1-2.20

Vondrák, J., Palice, Z., Khodosovtsev, A. \& Postoyalkin, S. 2010. Additions to the diversity of rare or overlooked lichens and lichenicolous fungi in Ukrainian Carpathians. Chornomors'kyi Botanichnyi Zhurnal 6(1): 6-34. https://doi. org/10.14255/2308-9628/10.61/1

Vondrák, J., Malíček, J. Šoun, J. \& Pouska, V. 2015. Epiphytic lichens of Stužica (E Slovakia) in the context of Central European old-growth forests. Herzogia 28: 104-126. https://doi. org/10.13158/heia.28.1.2015.104

Vondrák, J., Urbanavichus, G., Palice, Z., Malíček, J., Urbanavichene, I., Kubásek, J. \& Ellis, C. 2019. The epiphytic lichen biota of Caucasian virgin forests: a comparator for European conservation. Biodiversity and Conservation 28: 3257-3276. https://doi.org/10.1007/s10531-019-01818-4

Wirth, V., Hauck, M. \& Schultz, M. 2013. Die Flechten Deutschlands. 2 Bände. E. Ulmer, Stuttgart. $1244 \mathrm{pp}$.

Yatsyna, A. 2014. Lichens from manor parks in Minsk region (Belarus). Botanica Lithuanica 20(2): 159168. https://doi.org/10.2478/botlit-2014-0016

Yatsyna, A. P., Gagarina, L. V., Konoreva, L. A. \& Chesnokov, S. V. 2018. Lichens and closely re- 
lated fungi of manor parks of the Mogilev region (Republic of Belarus). Bulletin of Bryansk dpt. of RBS 14(2): 26-42 (in Russian, English abstract).

Zahlbruckner, A. 1923. Catalogus Lichenum Universalis 2. Bornträger, Leipzig. 815 pp.

Zhdanov, I. S. \& Dudoreva, T. A. 2008. Lichen flora of Kandalakshsky State Reserve (Murmansk Re- gion): history of investigations and first results. In: Fundamental and applied problems in botany at the beginning of XXI century. Proceedings of XII congress of Russian Botanical Society, part 2 (in Russian). Petrozavodsk. Pp. 189-192. 